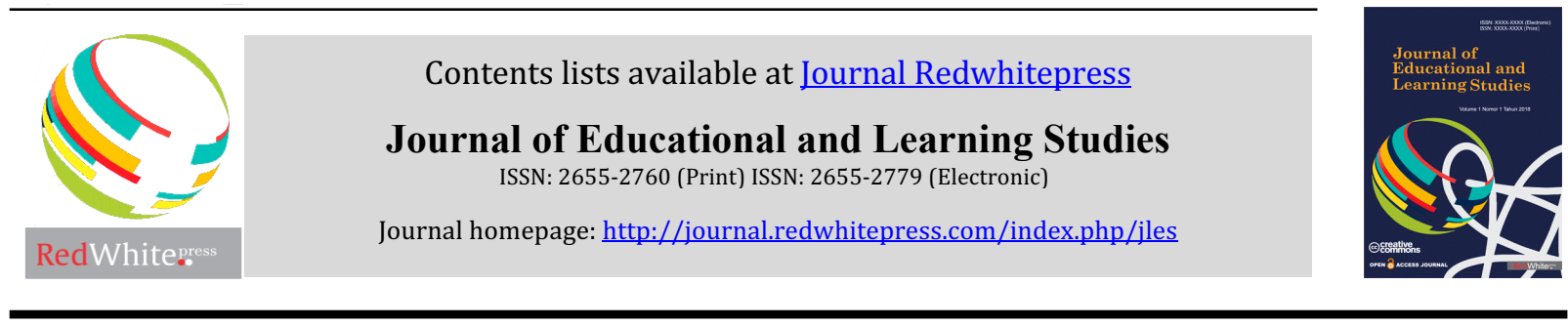

\title{
Contribution of Self Confidence and Peer Conformity to Interpersonal Communication
}

\author{
Muhammad Riswan Rais ${ }^{1}$, Marjohan $^{1}$ \\ ${ }^{1}$ Universitas Negeri Padang
}

\begin{tabular}{l} 
Article Info \\
\hline Article history: \\
Received Apr $12^{\text {th }}, 2020$ \\
Revised Jun $20^{\text {th }}, 2020$ \\
Accepted Aug $26^{\text {th }}, 2020$ \\
\hline
\end{tabular}

\section{Keyword:}

Self-Confidence

Peer Conformity

Interpersonal Communication

\begin{abstract}
This research was motivated by the low ability of the students of MAN 1 Mandailing Natal in communicating well interpersonal. Self-confidence and peer conformity are factors that are thought to affect interpersonal communication. This study aims to describe: self-confidence, peer conformity, and interpersonal communication, the contribution of self-confidence to interpersonal communication, the contribution of peer conformity to interpersonal communication, the contribution of confidence and peer conformity. Peers together on interpersonal communication. This research uses a descriptive correlational quantitative method. The study population was all students of MAN 1 Mandailing Natal, totaling 1130 people, a sample of 295 people, who were selected by proportional random sampling technique. The instruments used were self-confidence instruments, peer conformity instruments and interpersonal communication instruments. The data were analyzed using descriptive statistics, simple regression, and multiple regression. The findings of the study show that: on average, students' self-confidence is in the high category, but efforts are needed to further improve it, peer conformity is in the high category, efforts are needed to reduce negative peer conformity, students' interpersonal communication is in the good category, but there are some students who are not good at communicating, self-confidence contributes $47.8 \%$ to interpersonal communication, peer conformity contributes to interpersonal communication by $19.2 \%$, and self-confidence and peer conformity together contribute to interpersonal communication by $49.5 \%$.
\end{abstract}

(C) 2020 The Authors. Published by Redwhitepress.

This is an open access article under the CC BY-NC-SA license

(https://creativecommons.org/licenses/by-nc-sa/4.0/

\section{Corresponding Author:}

Muhammad Riswan Rais

Universitas Negeri Padang

Email: riswanrais@gmail.com

\section{Introduction}

Humans will experience developments in their lives, both advanced and vice versa. According to Santrock (2003), one of the developments that humans must go through is development during adolescence. Adolescence is a period of development between childhood and adulthood which involves biological, cognitive, and socio-emotional changes. Kay (Yusuf, 2009) explained that adolescence has several developmental tasks, one of the tasks of adolescent development is developing skills in terms of communicating and learning to interact between peers or other people, both individually and in groups. Interpersonal communication skills are very important abilities for every teenager so that they are able to interact with their friends at school and in their surroundings. 
Post \& Mahon (Sabanci, 2018) explains that interpersonal communication is the exchange of ideas, opinions and information through writing or spoken words, symbols, or actions. In addition, according to DeVito (2011) interpersonal communication can be interpreted as sending and receiving messages between one individual and another, or a group of individuals, with effects and some direct feedback. According to Mulyana (2008) through interpersonal communication, individuals will be able to learn not only about others themselves, but also feel who they are. This can happen because the people around him show their respective behavior.

Packard (Dewi et al., 2014) states that if an individual experiences failure in interpersonal communication with others, the individual will become aggressive, delusional, physically and mentally ill, and may even experience flight syndrome (wanting to escape from his environment). So individuals who are not able to communicate properly and correctly will experience difficulties in making social relationships with other people. Various problems that arise in communicating include not having good interpersonal communication skills. This is in line with the data from research conducted by Aswida (2012) which shows that $76.76 \%$ of class X students of SMA Negeri 7 Padang experience anxiety in communicating which causes students to have a bad tendency to communicate with other people and their social environment. Research conducted by Astuti (2013) shows that 62\% of SMP Muhammadiyah I Melati Sleman Yogyakarta students only have interpersonal communication skills which are in the sufficient category. Furthermore, research conducted by Fithriyana (2014) shows that $40.23 \%$ of interpersonal communication of Nurul Islam Semarang students is in the low category. In addition to the data listed in the previous paragraph, the author also includes other data obtained from several studies that have been carried out related to interpersonal communication, the authors compile them in tabular form, as for the data.

Table 1. Data related to Student Interpersonal Communication

\begin{tabular}{cccccc}
\hline \multirow{2}{*}{ Year } & \multicolumn{5}{c}{ Range (\%) } \\
\cline { 2 - 6 } 2012 & Very High & High & Moderate & Low & Very Low \\
2014 & 10 & 12,5 & 18,75 & 35 & 23,75 \\
\hline
\end{tabular}

Source (Aminudin, 2012) \& (Widya, 2014).

Based on the data listed in table 1, it can be seen that the differences in students 'interpersonal communication skills from 2012 and 2014. In 2012, data obtained from the results of research conducted by Aminudin (2012) showed that students' interpersonal communication was $10 \%$ very high category, $12,5 \%$ high category, $18.75 \%$ medium category, $35 \%$ low category, and $23.75 \%$ very low category. This shows that the percentage of interpersonal communication skills is still in the low category and really needs more efforts to improve it.

Furthermore, data in 2014 obtained from the results of research conducted by Widya (2014) showed that students' interpersonal communication skills were $2.4 \%$ very high category, $6.9 \%$ high category, $23.17 \%$ medium category, $47.56 \%$ category low, and $20.73 \%$ very low category. The data above shows that students still really need efforts to improve their interpersonal communication skills. To overcome this, it must first be known what factors affect interpersonal communication. DeVito (2011) explains that interpersonal communication is influenced by: (1) perception, (2) self-concept, (3) self-awareness, (4) language (verbal and non-verbal), (5) culture and (6) group influence. divided into three, namely; (a) idea development groups, (b) personal development groups, and (c) educational or study groups. Furthermore, DeVito (2011) states that the characteristics of interpersonal communication can be seen from one's self-confidence.

According to Wulandari (2018) self-confidence is the basic capital for development in self-actualization or exploration of all abilities within oneself, with confidence that a person will be able to know and understand himself. This is in accordance with the opinion of Tuncel (2015) which states that self-confidence has an important role in meeting basic human needs such as success and happiness. Rakhmat (2013) states that people who lack self-confidence will tend to avoid communication situations. This means that self-confidence is an important aspect of personality for every individual, especially in communication

In addition to self-confidence, peer conformity also affects interpersonal communication. In line with DeVito's opinion that the factors that influence interpersonal communication are personal development groups and this education and learning group are within the scope of peer-to-peer communication in line with the 
opinion of Santrock (2007) explaining that peers are adolescents who have the same age or level of maturity and maturity and involves a relatively large amount of intimacy in the group. Teenagers usually form a peer group or the term is popular to form a gang. Peer groups are groups of individuals with approximately the same age, social background and attitudes, who choose the same type or school activity or leisure activity. Peer groups usually have the same characteristics of behavior displayed by each member. The characteristics are how to interact or communicate, appearance models, ways of behaving, interests, attitudes towards teachers, parents and towards other groups. Tolley (2013) says conformity is a part that can affect the lives of adolescents where adolescents are always looking for friends, and it continues into adulthood. So that it can affect how they interact and communicate with the surrounding environment.

According to Myers (2012) conformity is a change in a person's behavior or beliefs as a result of real or imagined group pressure. Adolescents assume that if they behave and look like members of a popular group, the opportunity to be able to join and be accepted in the popular group is greater. Conformity within the circle of friends has two characteristics, namely; (1) conformity that is negative in nature, and (2) conformity that is positive. In this study, what will be discussed is negative conformity. Negative conformity can be in the form of dirty language use, stealing, making fun of parents and teachers. In a bad or negative friendship environment can stimulate bad emotional reactions in adolescents. This can result in adolescents experiencing failure in the learning process and can eliminate the motivation of adolescents to learn so that a group of adolescents who like to be alone and do not want to interact except with their group members and make noise at school until dropping out of school due to the influence of the environment.

Santrock (2013) suggests that strong conformity with peers can result in adolescents behaving negatively, such as communicating using careless language without courtesy, lying, stealing, and can lead to teasing teachers and parents. This pattern of communication between peers is also assumed to be one of the factors that can reduce students' interpersonal communication.

The opinion above can be interpreted that self-confidence and peer conformity affect students' ability to communicate. Students who do not have good beliefs will tend to avoid communication situations and will affect the implementation of their daily effective life, especially in learning activities, as well as students whose peer conformity is negative can result in adolescents experiencing failure in the learning process and can eliminate adolescent motivation to learn until a group of adolescents who like to be alone and do not want to interact except with their group members and make noise at school and drop out of school due to the influence of this environment Guidance and Counseling (BK) as an integral part of educational activities has an important role in development efforts student abilities, which are related to the effective daily life activities of students. Based on the explanation above, the researcher is interested in conducting research on the contribution of self-confidence and peer conformity to students' interpersonal communication.

\section{Method}

This research uses correlational quantitative method. The population of this study were all students of MAN 1 Mandailing Natal, totaling 1130 students. The sample selection was done by using proportional random sampling technique. Proportional random sampling is a way of determining the number of samples for each class, so that there is a balanced comparison between the size of the sample and the population of each group, the formula proposed by Yusuf (2013) can be used as follows, so that 295 students were obtained as the research sample. Data analysis using descriptive statistics, simple regression, and multiple regression. Data analysis was assisted by using the SPSS version 20.00 program.

The instruments used in this study were self-confidence instruments, peer conformity instruments, and interpersonal communication instruments with validity tests carried out using the help of Statistical Product and Service Solution (SPSS version 20.00). decision making is done by comparing rcount with $\mathrm{r}_{\text {tabel }}$ at $\mathrm{n}=50$ and $\alpha=0.05$, namely 0.2732 . if $\mathrm{r}_{\text {count }} \geq 0.2732$ then the research instrument item is declared valid and if $\mathrm{r}_{\text {count }} \leq$ 0.2732 then the research instrument item is declared invalid. Following are the results of the validity test of the research instrument items can be seen in the following table. 
Table 2. Results of the Research Instrument Item Validity Test

\begin{tabular}{cccc}
\hline Variable & \multicolumn{3}{c}{ Statement Item } \\
\cline { 2 - 4 } & Testing & Invalid & Research \\
\hline Self-Confidence & 42 & 9 & 33 \\
Peer Conformity & 32 & 2 & 30 \\
Interpersonal & 39 & 3 & 36 \\
Communication & & & 99 \\
Number of & 113 & 14 & \\
Statement Items & & & \\
\hline
\end{tabular}

Furthermore, reliability refers to the extent to which a measuring instrument consistently measures what is being measured. Yusuf (2013) explains that reliability is the consistency or stability of the score of a research instrument against the same individual and given at different times. For the reliability test, the Cronbach's Alpha formula was used (Arikunto, 2010). Based on the results of data processing, the Cronbach Alpha value for the self-confidence variable was 0.879 , the peer conformity variable was 0.895 . and the interpersonal communication variable was 0.726. Based on the Cronbach Alpha value, the two instruments were declared reliable.

\section{Results and Discussions}

The data in this study include self-confidence (X1), peer conformity (X2), and interpersonal communication (Y). The following is a description of the research data.

\section{Self Confidence (X1)}

Description of self-confidence data, amounting to 295 respondents can be seen in Table 3 .

Table 3. Distribution of Frequency and Percentage of Self Confidence (X1

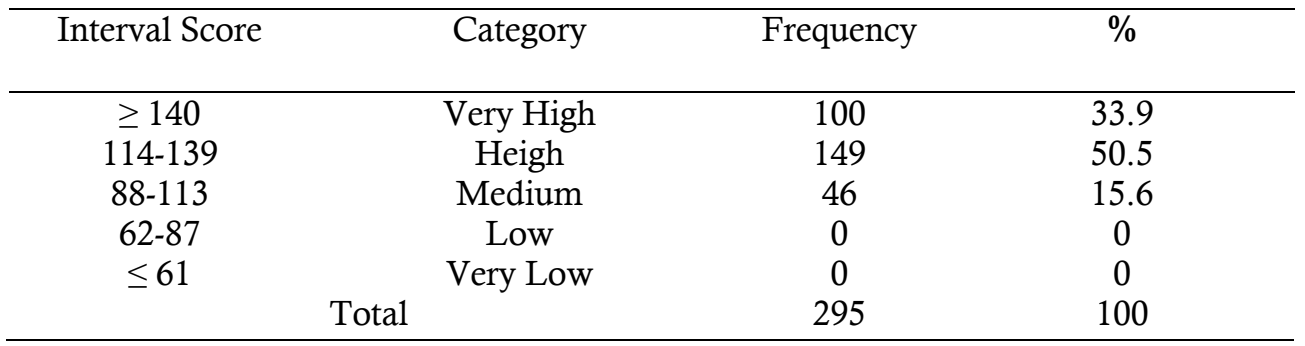

\section{Peer conformity (X2)}

Peer conformity data descriptions totaling 295 respondents can be seen in Table 4.

Table 4. Distribution of Frequency and Percentage of Peer Conformity (X2)

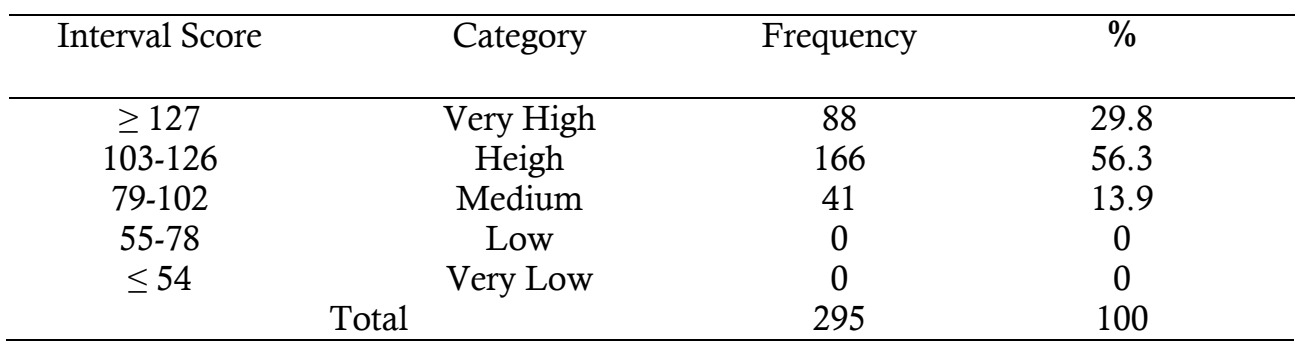


Interpersonal Communication (Y)

Descriptions of interpersonal communication data, amounting to 295 respondents, can be seen in Table 5 .

Table 5.Frequency Distribution and Percentage of Interpersonal Communication (Y)

\begin{tabular}{cccc}
\hline Interval Score & Category & Frequency & $\%$ \\
\hline$\geq 152$ & Very Good & 57 & 19.3 \\
$123-151$ & Good & 160 & 54.2 \\
$94-122$ & Good Enough & 78 & 26.4 \\
$65-93$ & Not Good & 0 & 0 \\
$\leq 64$ & So not Good & 0 & 0 \\
& Total & 295 & 100 \\
\hline
\end{tabular}

\section{Testing Data Analysis Requirements}

The data analysis requirements test carried out on the data of this study are the normality test, linearity test and multicollinearity test.

\section{Normality Test}

Table 6. Normality Test Results

\begin{tabular}{cccc}
\hline Variable & Asymp. Sig. & significance & Information \\
\hline $\mathrm{X}_{1}$ & 0.300 & & Normal \\
$\mathrm{X}_{2}$ & 0.132 & 0.05 & Normal \\
$\mathrm{Y}$ & 0.401 & & Normal \\
\hline
\end{tabular}

\section{Linearity Test}

Table 7. Self Confidence Linearity Test Results (X1), Peer Conformity (X2), with Interpersonal Communication $(\mathrm{Y})$

\begin{tabular}{ccccc}
\hline Variable & $\mathrm{F}_{\text {count }}$ & $\mathrm{F}_{\text {table }}$ & Sig. & Information \\
\hline $\mathrm{X}_{1}-\mathrm{Y}$ & 268.165 & 3.028 & 0.000 & Linear \\
$\mathrm{X}_{2}-\mathrm{Y}$ & 70.925 & 3.028 & 0.000 & Linear \\
\hline
\end{tabular}

\section{Multicollinearity Test}

Table 8.Multicollinearity Test Results Between Self Confidence (X1) and Peer Conformity (X2)

\begin{tabular}{cccc}
\hline Variable & Tolerance & VIF & Information \\
\hline & (Constant) & & Multicollinearity does not \\
$\mathrm{X}_{1}$ & 0.777 & 1.287 & occur \\
$\mathrm{X}_{2}$ & 0.777 & 1.287 & \\
\hline
\end{tabular}

\section{Contribution of Confidence and Peer Conformity to Interpersonal Communication}

The results of the analysis of the contribution of confidence to interpersonal communication and the analysis of the contribution of peer conformity to interpersonal communication and the results of the analysis of the contribution of confidence and peer conformity together to interpersonal communication can be seen in Table 5. 
Table 5.The Results of Simple Regression Analysis and the Significance Test of X1 for Y and X2 for Y, and X1, X2 simultaneously for Y

\begin{tabular}{cccc}
\hline Model & $\mathrm{R}$ & $\mathrm{R}$ Square & Sig. \\
\hline $\mathrm{X}_{1}-\mathrm{Y}$ & 0.691 & 0.478 & 0.000 \\
$\mathrm{X}_{2}-\mathrm{Y}$ & 0.441 & 0.192 & 0.000 \\
$\mathrm{X}_{1} . \mathrm{X}_{2}-\mathrm{Y}$ & 0.704 & 0.495 & 0.000 \\
\hline
\end{tabular}

Table 5 shows the results of simple regression analysis and a significant test between self-confidence and interpersonal communication that the $\mathrm{R}$ value is 0.691 , which shows the regression coefficient between selfconfidence on interpersonal communication, with a significant level of 0.000 . The value of R Square (R2) is 0.478 , which means that $47.8 \%$ of the variation in the level of interpersonal communication can be explained by self-confidence, while the remaining $52.2 \%$ is explained by other variables.

Furthermore, in Table 5 shows the results of simple regression analysis and a significant test between peer conformity and interpersonal communication that the $\mathrm{R}$ value is 0.441 which indicates the regression coefficient between peer conformity and interpersonal communication, a significant level of 0.000 . The value of R Square (R2) is 0.192 , meaning that $19.2 \%$ of the variation in the height and low of interpersonal communication can be explained by peer conformity, while the rest contributes to peer conformity to interpersonal communication, while the remaining $80.8 \%$ is explained by other variables. And in Table 5 also shows the results of simple regression analysis and a significant test between selfconfidence and peer conformity to interpersonal communication that the $\mathrm{R}$ value is 0.704 , which indicates a multiple regression coefficient between self-confidence and peer conformity on interpersonal communication, with a significant level of 0.000 . The value of $R$ Square (R2) is 0.495 , which means that $49.5 \%$ of the variation in the height and low of interpersonal communication can be explained together by self-confidence and peerto-peer confidence, while the remaining $50.5 \%$ is explained by other variables that have not been examined in this study.

\section{DISCUSSION}

\section{Self-Confidence}

Based on the results of the research data analysis, it is known that students' self-confidence is in the high category. Based on the achievement of each indicator, it is known that all indicators are in the high category. This means that the confidence of the students of MAN 1 Mandailing Natal in communicating is good.

Lauster (2006) describes five aspects that affect individual self-confidence as follows: 1) self-confidence, which means the individual's positive attitude about himself, and how the individual understands everything that is in him, is able to develop his strengths and be able to understand his shortcomings, 2) optimistic, namely a positive attitude who always has a good view of everything, individuals who have an optimistic attitude are not afraid of failure and are able to be bankable and learn from previous failures, 3) objective, namely the attitude of individuals to judge everything according to the truth that should be, 4 ) responsible, namely the individual's willingness to bear everything that has become a consequence of what has been done, be it good or bad consequences, and 5) rational and realistic, namely the ability to analyze problems or events using a reasonable mind.

Individuals who have high confidence fulfill the five aspects mentioned above.According to Aldi (2020) the self-confidence that a person has can increase expectations for achievement. With the existence of high self-confidence will increase the abilities possessed by individuals, including in communication. Therefore Guidance and Counseling teachers or counselors must continue to train and develop student self-confidence to stay good and improve it to be even better, because when students' self-confidence is low, students will avoid communication situations and prevent these students from optimizing their abilities.

\section{Peer Conformity}

The results of the research data analysis showed that on average the overall peer conformity was in the high category. This means that the conformity made by peers is indeed high so that students lack selfconfidence and in the end students cannot interact or communicate well, and feel students must follow what is required in their group to be accepted in the group. Students or adolescents must be able to select their environmental interactions, so that the conformity that is formed is positive conformity, because it will have a good impact on him, on the other hand, if this conformity cannot be interpreted properly in a negative sense, 
then this conformity will be one of the triggers for things to happen. negative ones (Mawardah \& Adiyanti, 2014).

As in the third indicator, which is fulfilling other people's expectations in item number 15, namely "even though I am not comfortable, I try to follow the rules in the group" as well as in the first indicator, namely the desire to be liked in item number 1, namely "I do not want to be isolated so I follow the rules set by friends ". This refers to the condition of students who are not confident and do not want to be isolated by their friends so that they must follow the rules in the group even though students feel uncomfortable so that it interferes with student interactions with other people and student communication.

Based on the explanation above, it can be understood that students' interpersonal communication interactions cannot be separated from the existence of peer conformity so that students feel accepted in the group. Therefore there needs to be an effort by the Counseling Guidance teacher to provide services in schools through optimal personal and social guidance, this is very important to help students develop their potential and practice students' self-confidence in communicating.

\section{Interpersonal Communication}

Based on the results of the research data analysis, it is known that the interpersonal communication of students of MAN 1 Mandailing Natal is in a good category. This means that it is in line with one of the tasks of adolescent development, according to Prayitno (2006), one of the duties of adolescents is to like, listen to or pay respect to others. This means that students as individuals who have developmental tasks should be able to communicate well, because it is part of a developmental task that must be fulfilled. In addition, with good communication, individuals can carry out their role as social beings.

This needs to be maintained and improved. Therefore, it takes the role of the Counseling Guidance teacher or counselor in handling this matter. The guidance counselor or counselor can provide materials based on items at low indicators, namely the importance of the ability to accept other people's opinions, how to behave in listening to other people's opinions. These materials can be provided through various Guidance and Counseling services.

Sahputra (2016) based on the results of his research revealed that interpersonal communication can be improved through the provision of information services, which aims to meet student shortages of information relating to improving interpersonal communication. So it can be concluded that to improve interpersonal communication students can be done through guidance and counseling services. And based on the research results, the interpersonal communication of students of MAN 1 Mandailing Natal is in a good category, so it needs to be maintained and improved through various types of Counseling Guidance services so that students can develop their potential optimally.

\section{Contribution of Confidence to Interpersonal Communication}

The results showed that self-confidence contributed significantly to students' interpersonal communication. This finding was obtained based on data analysis that the contribution of self-confidence to students' interpersonal communication was $47.8 \%$, while the rest $(52.2 \%)$ explained other variables. This means that self-confidence is one of the factors that contribute to students' interpersonal communication. Sahputra (2016) 's research results show that self-confidence contributes significantly to interpersonal communication. These findings were obtained based on data analysis which showed that the contribution of self-confidence to interpersonal communication was $19.6 \%$. This is in accordance with the results of research conducted by researchers that self-confidence contributes to interpersonal communication. This means that the higher the individual's self-confidence, the better the interpersonal communication is, on the contrary, if the individual's self-confidence is low, it will result in bad interpersonal communication. This is in line with the opinion of Rakhmat (2013) which states that if someone feels inferior, then he has difficulty communicating his opinion. or his thoughts towards people he respects and is unable to speak in public.

Based on the description above about self-confidence, it can be said that self-confidence is one of the determining factors in interpersonal communication, because individuals who have self-confidence will be skilled in communicating. Therefore, students who have high and moderate self-confidence can optimize their self-confidence as well as possible. 


\section{Contribution of Peer Conformity to Interpersonal Communication}

The results showed that peer conformity contributed significantly to students' interpersonal communication. This finding was obtained based on data analysis that the contribution of peer conformity to students' interpersonal communication was $19.2 \%$. While the rest $(80.8 \%)$ explained other variables. This means that peer conformity is one of the factors that contribute to interpersonal communication.

Santrock (2013) explains that strong conformity with peers can result in adolescents behaving negatively, such as communicating using careless language without courtesy, lying, and can lead to playing tricks on teachers and parents. This pattern of communication between peers is also assumed to be one of the factors that can reduce students' interpersonal communication. Niâ's research (2010) revealed that the higher the negative peer influence, the lower the students' interpersonal communication skills.

Students who get high negative conformity from peers will feel that they must be able to fit in the group and do anything including not being themselves and following the habits and ways of intacting their friends. Therefore, students should be more able to develop their potential so that students tend not to feel alienated by their friends, then it is hoped that peers can have a psychological influence so that students can be themselves and be able to interact well, especially communicate well interpersonal.

\section{Contribution of Confidence and Peer Conformity to Interpersonal Communication}

The results showed that self-confidence and peer conformity together significantly contributed to students' interpersonal communication. This finding is based on data analysis that the R Square (R2) is 0.495 , this means $49.5 \%$, the variation in the height and low of interpersonal communication can be explained jointly by self-confidence and peer conformity, while the remaining $50.5 \%$ is explained by other variables.

Based on the findings above, it can be seen that self-confidence and peer conformity are factors that affect students' interpersonal communication. Self-confidence is useful for courage when communicating with others. so that in the end individuals who have high self-confidence, will find it easier and help in the process of interacting, especially in interpersonal communication. Likewise with negative peer conformity which increasingly makes students feel afraid or anxious and insecure when interacting, especially interpersonal communication, so that negative peer conformity must be eliminated so that students can interact more easily and have confidence in interpersonal communication.

Students' interpersonal communication depends on the self-confidence achieved and positive peer conformity which makes students easily able to communicate well and be more confident in communicating their thoughts. Students who are considered to have good interpersonal communication skills are students who have self-confidence and can overcome various problems from their peers. Therefore, high self-confidence and positive peer conformity are needed so that students are able to communicate well interpersonal.

\section{Conclusions}

1. On average, the students' self-confidence in MAN 1 Mandailing Natal is in the high category. This means that on average students already have good confidence when communicating with their friends. His parents and others.

2. On average, the peer conformity of the students of MAN 1 Mandailing Natal is in the high category. That is, there are still many students who receive negative conformity from their peers so that students do not have good self-confidence and skills in interpersonal communication.

3. On average, the students' interpersonal communication at MAN 1 Mandailing Natal is in good category. This means that when communicating with other people, students already have good abilities in communicating thoughts and feelings correctly and correctly, understanding, receiving and providing support, and being able to solve problems that occur when communicating.

4. Self-confidence contributes to the interpersonal communication of students of MAN 1 Mandailing Natal by $47.8 \%(\mathrm{R}=0.691, \mathrm{R} 2=0.478$, and a significance of 0.000$)$. That is, the high level of students' interpersonal communication can be explained by self-confidence. It can be concluded that the higher self-confidence, interpersonal communication will increase for the better.

5. Peer conformity contributed significantly to the interpersonal communication of students of MAN 1 Mandailing Natal by $19.2 \%(\mathrm{R}=0.441, \mathrm{R} 2=0.192$, and a significance of 0.000$)$. That is, the level of 
student interpersonal communication can be explained by peer conformity. It can be concluded that, the lower the negative peer conformity, the better the students' interpersonal communication.

6. Mutual confidence and peer conformity contributed to the interpersonal communication of students of MAN 1 Mandailing Natal by $49.5 \%(\mathrm{R}=0.704, \mathrm{R} 2=0.495)$. That is, the level of interpersonal communication of students is not only influenced by one variable (self-confidence and peer conformity), but is influenced jointly by self-confidence and peer conformity. Thus, it can be explained that the higher the tendency for self-confidence and the higher the positive peer conformity, the better the interpersonal communication of the students. Individually self-confidence is more effective in contributing to students' interpersonal communication.

\section{References}

Aldi, A. H. (2020). Kontribusi antara kepercayaan diri dengan interaksi sosial terhadap presentasi diri pada peserta duta FKIP ULM tahun 2018. Jurnal Pelayanan Bimbingan Dan Konseling, 3(2), 132-138.

Aminudin, D. (2012). Efektivitas bimbingan teman sebaya dalam meningkatkan kemampuan komunikasi interpersonal siswa. Tesis. Bandung: Program Pascasarjana Universitas Pendidikan Bandung. Retrieved from http://repository.upi.edu.

Astuti, A.D., Sugiyo, \& S. (2013). Model layanan BK kelompok teknik permainan (games) untuk meningkatkan komunikasi interpersonal siswa. Jurnal Bimbingan Dan Konseling, 2(1), 50-56.

Aswida, Wela., Marjohan, dan Syukur, Y. (2012). Efektifitas layanan bimbingan kelompok dalam mengurangi kecemasn berkomunikasi pada siswa. Jurnal Ilmiah Konseling, 1(1), 1-11.

DeVito, J. A. (2011). Komunikasi antar manusia. (M. Agus, Ed). Jakarta: Karisma Publishing Group.

Dewi K.K.S, Sendayana, G., Antari, N. N. M., \& Erg, M. (2014). Kontribusi komunikasi interpersonal terhadap penyesuaian diri siswa kelas VIII SMP Negeri 2 Sawan Tahun Pelajaran 2013/2014. Jurnal Ilmiah Bimbingan Konseling Undiksha, 2(1). 26-34.

Fithriyana, A., \& Sugiharto, D. Y. P. (2014). Bimbingan kelompok dengan teknik permainan simulasi untuk meningkatkan kemampuan komunikasi antar pribadi siswa. Jurnal Bimbingan Konseling, 3(2), 138-142.

Lauster, P. (2006). Tes kepribadian. (D. H. Gulo, Ed). Edisi Bahasa Indonesia. Jakarta: Bumi Aksara.

Mawardah, M., \& Adiyanti, M. G. (2014). Regulasi emosi dan kelompok teman sebaya pelaku cyberbullying. Jurnal Psikologi, 41(1), 60-73.

Mulyana, D. (2008). Ilmu komunikasi. Bandung: PT Remaja Rosdakarya.

Myers, D. G. (2012). Psikologi Sosial Edisi Kesepuluh. Jakarta: Salemba Humanika.

Niâ, M., Hardjajani, T., \& Karyanta, N. A. (2010). Hubungan antara komunikasi interpersonal dan interaksi teman sebaya dengan penyesuaian sosial pada remaja di SMP Negeri 1 Sukoharjo. WACANA, 2(2), 85105.

Prayitno, E. (2006). Psikologi perkembangan remaja. Padang: Angkasa Raya.

Rakhmat, J. (2012). Psikologi komunikasi. Bandung: PT. Remaja Posda Karya.

Rakhmat, J. (2013). Psikologi komunikasi. Bandung: PT. Remaja Posda Karya.

Sabanci, A., Sahin, A., \& Özdemir, I. (2018). The correlation between interpersonal communication skills of inspection groups and their conflict management strategies. Online Submission, 4(4), 176-196.

Sahputra, D., Syahniar, S., \& Marjohan, M. (2016). Kontribusi kepercayaan diri dan kecerdasan emosi terhadap komunikasi interpersonal siswa serta implikasinya dalam pelayanan bimbingan dan konseling. Konselor, 5(3), 182-193.

Santrock, J. W. (2003). Adolescence: perkembangan remaja. (S. Sherly, Ed). Jakarta: Erlangga.

Santrock, J. W. (2007). Remaja Jilid 2. (B. Widyasinta, Ed). Jakarta: Erlangga.

Santrock, J. W. (2013). Perkembangan remaja. edisi keenam. (S. B. Adelar, Ed). Jakarta: Erlangga.

Tolley, R. A. (2013). Conformity: drug and alcohol abuse within adolescent communities. USA: Lincoln Memorial University.

Tuncel, H. (2015). The relationship between self-confidence and learning Turkish as a foreign languange. Educational Research and Reviews, 10(18), 2575-2589.

Widya. (2014). Hubungan antara konsep diri dengan kemampuan komunikasi interpersional dan implikasinya terhadap Bimbingan dan Konseling. Tesis. Padang: Program Pascasarjana UNP. Retrieved from http://repository.unp.ac.id.

Wulandari, G. (2018). Hubungan antara konsep diri dengan kepercayaan diri siswa kelas VIII di MTS Al-Ihsaniyah. Universitas Jambi. Retrieved from http://repository.unja.ac.id/id/eprint/3589.

Yusuf, Syamsu. (2009). Psikologi perkembangan anak dan remaja. Bandung: RosdaKarya. 